and duration in patients with $T$ cruzi infection. Measurement of antibody concentrations may help in evaluating prognosis, and-to speculate further-their elimination could possibly arrest the progress to heart muscle failure and severe conduction defects that is otherwise inevitable in patients with chronic Chagasic cardiomyopathy.

1 Lancet, 1965, 1, 1150.

2 Cossio, P M, et al, Circulation, 1974, 49, 13.

3 Cossio, P M, et al, Circulation, 1974, 50, 1252

4 Teixeira, A R L, Teixeira, M L, and Santos Buch, C A, American fournal of Pathology, 1975, 80, 163.

5 Sterin Borda, L, et al, Cardiovascular Research, 1976, 10, 613.

${ }^{6}$ Santos Buch, C A, and Teixeira, A R L, Fournal of Experimental Medicine, 1974, 140, 38

7 Cossio, P M, et al, Medicina (Buenos Aires), 1976, 36, 287

${ }^{8}$ Cossio, P M, et al, American fournal of Pathology, 1977, 85, 533.

9 Teixeira, A R L, Teixeira, M L, and Santos Buch, C A, quoted by Santos Buch, $\mathrm{C} \mathrm{A}$, in Proceedings of the VII International Conference on Immunopathology fune 1976, ed P A Miescher. Basle, Schwabe, 1977.

10 Ribeiro dos Santos, R, Von Gal Furtado, C C, and Rodriques, W, in Proceedings of the 13th Congress Brazilian Society of Tropical Medicine, 1977, Abstract 62.

\section{Crush injuries}

Crush injuries still carry both high mortality and high morbidity rates. The problems they cause are well illustrated in the report by Brown and Nicholls ${ }^{1}$ of two young adults who were trapped by their legs for $6 \frac{1}{2}$ and 13 hours in the Moorgate disaster and who subsequently died after a long period of hospital care.

The outcome in these patients-admitted to London teaching hospitals with every facility for life supportemphasises how little progress we have made since this type of injury was first designated "the crush syndrome" in the second world war. ${ }^{2}$ Despite the advent of effective dialysis as treatment for post-traumatic oliguric renal failure, the overall mortality of $60-70 \%{ }^{3}$ has not changed substantially from that reported 25 years ago. ${ }^{4}$

Impairment of renal function is an early and crucial feature of the crush syndrome. Both the Moorgate victims had hyperkalaemia, oliguria, and haematuria on admission to hospital. The exact nature of the damage to the kidneys in such cases is still a matter for conjecture, but recent studies have shown that the renal lesion in crush injuries is not fundamentally different from that seen in association with other severe injury or major surgical operation. Nevertheless, today this type of deterioration in renal function is usually reversed or prevented by early and aggressive fluid therapy with crystalloids and colloids, and the judicious use of diuretics. Champion et $a l^{5}$ reported that with these methods renal function was impaired in only 40 of 751 patients with multiple injuries affecting two or more systems. The interval between injury and the onset of renal failure varied, but the signs were usually apparent within the first 48 hours. Champion et al also claimed that impairment of renal function could be detected early on with the use of a "renal index" calculated from the daily urine volume and the serum creatinine and blood urea nitrogen concentrations. The earlier treatment is begun, the more effective it will be in preventing renal damage; so that in dealing with trapped patients where possible infusions should be started while they are awaiting release. In appropriate cases haemodialysis might perhaps be started soon enough to prevent deterioration of renal function, but such treatment has not yet been evaluated.
The Moorgate experience shows, however, that the crush syndrome includes many more features than those of renal failure. ${ }^{1}$ Dialysis may tide the patient over the period of once fatal uraemia and hyperkalaemia but he then has to face the possibility of failure of other organs and systems associated with multiple severe injuries. Indeed, the use of the term "crush syndrome" and other similar labels such as "shock lung" or "fat embolism" may be a disservice to the injured patient, concentrating attention as they do on a single organ or system to the exclusion of equally important problems elsewhere.

The integrated management of the crushed patient must include an assessment of all systems, but the most difficult decision is what to do with the damaged limbs-especially if (as in the Moorgate cases) the arterial pulses are still present. The limbs can occasionally be salvaged even after prolonged crushing. ${ }^{6}$ Nevertheless, as soon as it is apparent from the physical signs of gross swelling, lack of movement, and anaesthesia that most of the soft tissues are dead there should be no delay in taking the difficult decision to amputate. We should not have to relearn fundamental surgical principles, established in wartime, ${ }^{7}$ that both decompression by fasciotomy and limited excision are ineffective in such cases.

The major threat to life in these patients is uncontrollable sepsis, which in the end caused the deaths of the two Moorgate victims and accounted for $72 \%$ of the deaths in one major series. $^{3}$ Impaired host resistance is characteristic of both injured patients and those with renal failure, ${ }^{89}$ and further study of this aspect is needed urgently if we are to overcome these septic complications successfully.

The management of patients with multiple injuries requires experience and the collaboration of many specialties. Sadly, the policy in most parts of the country leads to the scattering of these patients through dozens of small, often ill-equipped, casualty departments. Until this approach is changed to one of centralising the care of major injuries in a few accident units, surgeons will acquire little worthwhile experience in the management of major trauma and its complications.

\footnotetext{
1 Brown, A A, and Nicholls, R J, British fournal of Surgery, 1977, 64, 397. 2 Bywaters, E G L, and Beall, D, British Medical Fournal, 1941, 1, 427.

${ }^{3}$ Lordon, R E, and Burton, J R, American fournal of Medicine, 1972, 53, 137.

4 Board for the Study of the Severely Wounded, Surgery in World War II. Washington Office of the US Surgeon General, Department of the Army, 1952.

${ }^{5}$ Champion, H, et al, Lancet, 1974, 1, 1125

${ }^{6}$ Graham, D, Andersen, R, Minnesota Medicine, 1975, 58, 529.

${ }^{7}$ Rush, B F, Teschan, P E, and Mundy, R, Archives of Surgery, 1958, 77, 807.

${ }^{8}$ MacLean, L D, et al, Annals of Surgery, 1975, 182, 207.

${ }^{9}$ Montgomerie, J Z, Kalmanson, G M, and Guze, L B, Medicine, 1968, 47, 1 .
}

\section{Surgeons and money}

One of the sharpest weapons of attack on "fee for service" systems is the contention that surgery increases as a function of recoverable fees. In an affluent society with a personal insurance system plastic surgery (to take but one example) will flourish; resources-both people and material-will be pulled into that area; and plastic surgeons will get richer. This argument, as it applies to the preservation or destruction of a private health sector in Britain, has been cogently and determinedly developed by the Radical Statistics Health Group in a recent pamphlet ${ }^{1}$ which, from an openly stated political point of view, makes a wide-ranging and in many 